Article

\title{
Compost effect on organic pepper and olive sapling growth
}

\author{
Alev Kir 1,*
}

1 Ministry of Agriculture and Forestry, Olive Research Institute, University Street No:43 Bornova, Izmir 35100, Turkey; alev.kir@tarimorman.gov.tr

* Correspondence: alev.kir@tarimorman.gov.tr

\begin{abstract}
To substitute of conventional manure and peat with alternatives sourcing from environmental conservation concerns, several promising alternatives has been attracting scientific parties' interest, recently. However, among them compost perform the best, mostly and support carbon sequestration and mitigation against climate change. The article describes the made locally produced $70 \%$ in volume olive pruning branches compost (COMP) performance in two trials as an organic amendment in pepper production and an olive sapling substrate during 2019-2021 organic management in Turkey. The application of COMP to pepper trial conducted using factorial randomised block design with 4 replications and 6 treatments increased total organic matter and soil organic carbon, significantly $(\mathrm{p}<0.05)$ as compared to non-used plots in two locations. The olive sapling trial was conducted using a randomised plot design with 4 replications and 4 treatments. After the 12 months of growth, compost had the largest architecture rooted plants significantly different $(\mathrm{p}<0.05)$. Fresh volume $\left(\mathrm{cm}^{3}\right)$ of COMP used saplings were obtained $35 \%$ less than $40 \%$ peat treatment, significantly $(\mathrm{p}<0.05)$ while $6^{\text {th }}$ month measurement was found as $40 \%$. It is concluded that to enhance circular economy recycling and composting olive pruning branches is lucrative for the country to reduce external input usage in organic horticultural production.
\end{abstract}

Keywords: Olive pruning; compost; recycling; Capsicum annuum L.; soil organic carbon (SOC); soil organic matter (SOM); olive young tree; Olea europaea L.; peat replacement.

\section{Introduction}

Conservation of soil fertility in company with having a low negative environmental impact, mitigation against climate change, enhancement of circular economy, and recycling organic plant based materials have increasing concerns in last decades on earth. One of the effective solution is co-composting of wood and plant residual parts in both onfarm scale and industrial area. Sustainable farming systems, in particular organic agriculture (=ecological=biological) movements, have been searching many dedicated methods to reach "mature compost" containing plant essential nutrients such as total nitrogen, available phosphorus and potassium as well as which is rich in beneficial microorganisms such as fungi. Among the enormous different bio-waste and methods, to enhance agricultural contribution to economy, "thermodynamic (warm)" farm scale composting under organic conditions is put under the one of the scopes of the article. Yield and quality effect of compost on horticultural crops depends on long term experiments when the issue is plant nutritional quality. The use of peat as propagation material in commercial production is increasingly calls to replacement of peat with a high quality compost. Considering carbon accumulation in soils compost elevates carbon sequestration in terrestroals. Support and disseminate of the application of weed and seed-free, plastic-free, rich in essential plant nutrients, stable and contain beneficial microorganisms compost is valuable to soil fertility. 
Compost is one of the fundamental tools in agroecological agriculture to obtain soil sustainable organic matter management [1] Fuchs et al., 2008. Composts are used in mainly horticultural plant production as a plant nutrient via help of microbiota activity in soil and compost itself. Moreover, plant nutrients that are difficult to use by plants in the soil items become available as compost is applied to lands. Locally available organic sources of plant nutrients which can be called as crop residue such as "wood chips" of horticultural tree pruning is one of the most important sources for supplying nutrients to the crop production land and for improving and ensuring the soil health. The optimum total soil organic matter (SOM) content in agricultural soils under organic management is the healing factor in such conditions if the application is planned and performed, proficiently, considering timing and amount of the compost.

Compost application pave the way the following procedures in the soil: Soil life (such as bacteria and fungi) effect on decomposition or stabilization of organic waste material's soil organic matter has been taking place in soil. An active and diverse community of soil life organisms enhance availability of soil oxygen and moisture at sufficient level. Those microorganisms take part in nutrient uptake, as well as prevent or minimize disease, enhance overall vigour and resilience to drought and other biotic and abiotic stresses, and improve the quality of the crop. The organic material is decomposed in the presence of oxygen the process is called "aerobic". Due to improper biodegradation of organic matter, unstable compost can compete for oxygen and nitrogen, causing poor plant growth and destroying crops or being phytotoxic to plants. Also, immature compost typically immobilizes nitrogen rather than releasing it for plant growth. This is because compost which is not stable continues to decompose even after it has been applied to the soil, in which case soil microorganisms take up nutrients to be used by plants. For this reason, compost should not be applied to the soil unless it has matured effectively. Application of immature organic matter to soil can affect negatively both crops and the environment due to the presence of phytotoxic compounds.

Because composting is suitable for a wide variety of materials, it is possible for a composting process to work in collaboration with other farms, municipalities and industry, composting, for example, manure, food processing waste from horse racing tracks, or organic waste from fields such as fields and home gardens. The basic elements in planning a compost plant are; to carry out field surveys and feasibility studies and to carry out the design by taking into account the conditions such as location, direction, climate data, slope; design a covered semi-open facility; choosing the composting method according to the conditions; develop a waste use plan and an operation and maintenance plan. Organic wastes consisting of materials such as vegetable and animal waste, kitchen waste, paper and cardboard; It is a very valuable soil improver that can be reintroduced to nature by decaying in the short and/or medium term. The product obtained as a result of composting will be beneficial as a soil conditioner as well as containing the plant nutrients needed by the plants. Organic wastes are very valuable in terms of productivity and nutritional value. Many agricultural wastes, from animal manures to walnut and chestnut wastes, from vegetable wastes to corn and sunflower stalks and tea waste, can be composted and used as soil physical and chemical improvers and for the nutrient needs of plants. However, these lignocellulose rich waste while contain valuable humid husk, on the other hand has a phytotoxic risk sourcing from the phenolic compounds existing in the branches and leaves which are hardly biodegradable in the agricultural soils as they used freshly [2] (Makas et al., 2000) and the phenol content can be reach high amounts [3] (Kir et al., 2021). Therefore, composting is essential for this kind of cases and recycling these waste to compost may poses soil protection and environment, as well. Because composting is a relatively flexible process, it is necessary to decide between alternative methods, locations and materials. The economic capacity aspects of the farm as well as the physical constraints of the site are decisive factors for the composting method when making decisions. Europe's soils are losing organic matter at an unsustainable rate due to land use changes, 
modern agricultural practices and climate change. It is estimated that almost half of European soil has low organic matter content, which reduces its ability to retain water and nutrients, and to store carbon. Primarily, this reduces the productivity of the land and farmers' ability to grow crops. Application of bio-waste or green compost, which probably a useful source of "stable" organic matter in the soil.

Best management practices identified during the demonstration showed that a 30- to 40-ton rate of composted material and a 15- to 20-ton rate of wood chips that are chipped to about the size of a quarter are optimal. Results were greater when material was disked or tucked into the top layer of the soil profile, as compared to being surface applied. Farmers benefit from application of this material because of higher yields, less chemical use, erosion control, and increased organic matter [4] (Koopmans and Zanen, 2007). Since soils are poor in organic matter, in general, organic matter storage and conversion; mineralization. A well-known positive effects of compost on soil structure, aggregate stability and water holding capacity are crucial in terms of improving the important parameters that will affect the fertility of agricultural soils.

Compost improves soil health and structure. In a quality structure that does not contain weed seeds that maintain their vitality, it both plays a role in suppressing weeds and does not carry new weeds to the soil. There are beneficial microorganisms in compost and these organisms have an effect on soil fertility and prevention of soil diseases. Compost reduces the bulk weight of the soil and increases the water holding capacity of the soil. In this way, soil fertility and water infiltration capacity increase. If the compost is obtained in high quality, it attracts attention as an organic fertilizer with a significant amount of nitrogen, phosphorus and potassium, which reacts slowly [5] (Alburquerque et al., 2012). It also contains micro elements. It also shows a buffering effect against high levels of mineral fertilization. Thus, the primary benefit of compost is that it improves soil structure and properties providing easy aeration and easy processing of the soil, increases the water holding capacity of the soil and prevents salinization in dry seasons. Buffers toxins and heavy metals in the soil. Compost provides the rehabilitation of polluted soils and most importantly regulates the $\mathrm{pH}$ balance of the soil. Soil $\mathrm{pH}$ is essential in the uptake of plant nutrients from the soil solution.

The use of "peat" in seedlings and nurseries is common in our country as well as all over the world. However, risky, dangerous and permanent losses occur for nature in wetlands where material is removed from peat fields. The widespread use of quality compost instead of "peat" will be an important step in nature protection and sustainable environmental health [6, 3] [Gruda, 2019; Kir et al., 2021]. The success to be achieved in many project activities are an important start in this regard [7] [Clark and Cavigelli, 2005]. Besides, many countries have rising concerns phase-out peat mainly with green compost. In this respect, the UK government announced reduction peat usage until 2025.

Compost is also one of the leading measures to be taken for climate change and plays an important role in sequestration of carbon in soils. The environmental protection made by the use of compost by the carbon held by the peat beds in the earth is increasing exponentially. Recent studies report successful results in replacing compost with peat [8] Raviv 2015). Composting process results in a mixture of organic carbon compounds that contribute to the soil's carbon pool. Strategies to tackle climate change in the past few years have also emphasised the potential 'sequestration' of carbon in soils connected to use of soil improvers. At the EU level, the report 'Soils and climate change' has drawn attention to the key role of carbon pools in soils in the global carbon balance, and the potential for sequestration to mitigate climate change. In one of its latest reports of [9] IPCC released in 2021, called attention to the need to preserve and increase soil organic matter to mitigate climate change.

Among the certified organic crop productions in Turkey, olive tree ranks as approximately $8 \%$ of the total organic plant production and is the largest proportion of horticultural crops, while the organic pepper is low [10] ( Willer et al., 2020). Additionally, to 
include residual plant materials into the circular economy recycling of the fruit tree pruning branches is a fundamental action on earth against carbon producing activities to dispose of the great amount of garbage, because, for instance, calculated average coefficient olive pruning is approximately $34 \mathrm{~kg}$ per tree, annually, in Turkey [11] ( Cicek et al., 2021).

From 66 countries exporting peat, the value amounts to $\$ 1.35$ billion per year, whereas the imports of peat exceeded \$1.43 billion in 121 countries in 2019 [12] (Anonymous, 2020). For use in growing media, it is the combination of the physical, chemical and biological characteristics of peat that has made it exceptionally suitable as a growing medium, with the physical structure allowing for an appropriate balance of air and water (air-filled porosity) in the medium to facilitate healthy root growth and the cation exchange capacity of the organic material prevents leaching of mobile nutrients [13] (Bek et al 2020). However, UK Government announced that peat will be banned in horticultural production because of the concerns of the peatlands carbon sequestration capacity [14] (Anonymous, 2021) This development can be leading effects in all over the world.

The objective of the current study was to investigate the compost which was sourced " $70 \%\left(\mathrm{v} \cdot \mathrm{v}^{-1}\right)$ olive pruning $+10 \%\left(\mathrm{v} \cdot \mathrm{v}^{-1}\right)$ aromatic and medicinal plant $+18 \%\left({\left.\mathrm{v} . \mathrm{v}^{-1}\right) \text { grass }}^{-1}\right.$ clippings" effect on soil organic matter (SOM) and soil organic carbon (SOC) in organic pepper production as a soil organic fertiliser and olive saplings vegetative performance as a growing media. The reduced fresh animal fertiliser $\left(2 \%, v^{-1}\right)$ used compost was targeted, initially; thus, the tested compost was, mainly, plant based. Testing effects of compost carbon sequestration and total organic matter in soil of the organic pepper production is in conjunction with global warming issue is crucial topic demanding local datasets and scientific results to ensure a contribution to reduce of atmospheric carbon dioxide which is a main problem according to many publications. On the other hand, a substrate, in general and at farm level, is not fertilised in young olive tree chain of production, trade and even in gardener site that saplings were planted in Turkey. Thus, compost could be a good solution as an olive sapling substrate in replacement of peat which is highly contentious input.

\section{Materials and Methods}

\subsection{Olive Sapling Pot Trial (12 month) Method}

The trial was carried out under controlled conditions at the Olive Research Institute (ORI) in Bornova (Izmir, Turkey). This paper describes the 12 months of the growing period of the saplings, from April 2019 to April 2020 and the saplings are expected to be ready for planting in field by the end of April 2021. 4-month-old saplings were cv. 'Gemlik' (Olea europaea L.) were used as the planting material. This is a cultivar of widespread use in Turkey and it is known to be easily rooted [15, 16] (Ozkaya, 1997; Ozkaya and Celik,1999). The plants were grown in a greenhouse where the temperature was kept between 16 and $28^{\circ} \mathrm{C}$.

The trial was conducted using a randomised plot design with 4 replications and 4 treatments. Each replicate was composed of 48 pots and hence there was a total of 192 pots ( 4 replications $\times 4$ treatments $\times 12$ pots). The following growing media treatments were compared:

1) (COMP) compost made from locally available plant waste material (chipped olive branch pruning $70 \% \mathrm{v} / \mathrm{v}$, medicinal and aromatic plant residues $10 \% \mathrm{v} / \mathrm{v}$, grass cuttings $18 \% \mathrm{v} / \mathrm{v}$ and, horse manure $2 \% \mathrm{v} / \mathrm{v}$; (compost used in pots: $100 \% \mathrm{v} / \mathrm{v}$ );

2)(FIBRE) mixture of chippedand extruded (to fibre) olive branch pruning (50\% extruded $+50 \%$ non-extrudedchipped material, v/v),

3)(SAND)a commercial mixture (sand 90\%+vermiculite 10\%,v/v)(control), and trol).

4)(PEAT+) a commercial mixture) (peat $40 \%+$ coco coir $40 \%+$ perlite $20 \%$, v/v)(con-

SAND and PEAT+ were both commercially available growing media for olive saplingswith a widespread use in Turkey. Both controls are permitted for use in certificated 
organic production, and they are not amended with any mineral or organic fertilisers or any beneficial microorganisms. For the extrusion, chipped olive branch pruning material was sent to Leibniz Institute for Agricultural Engineering and Bioeconomy (ATB) in Potsdam, Germany [17] (Dittrich, 2021). After the extrusion, the fibre material was sent back to Turkey to be used in the study. The extruded fibre was subject to pre-testing in 10 pots with olive saplings, out of which no plant survived, where asthe 10 by 10 saplings pretested with COMP, SAND, and PEAT+ had survival rates of 95\%, 100\%, and 100\%. Chemical analysis of the substrates revealed a need to apply additional nutrients to the FIBREtreatment and this was done by application of freeze-dried fish powder and vermicompost tea, both inputs permitted for use in organic growing. No fertiliser was added to any of the other treatments at the start of the experiment. Young trees are known to need higher rates of phosphorus and potassium than nitrogento establish a strong root system. The fish fertiliser was derived from haddock (Merlangius euxmus) which had been freezedried and ground to a powder (supplying $75 \mathrm{mg} \mathrm{P}_{2} \mathrm{O}_{5}$ per pot), before planting and 1 month after planting. Additionally, locally produced, commercially available, and organic

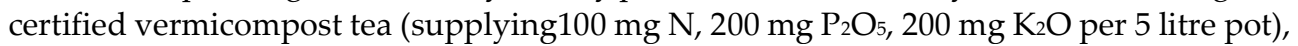
Bacillus spp. $\left(6 \times 10^{7} \mathrm{cfu} / \mathrm{ml}\right)$, and Glomus spp. $\left(1 \times 10^{4} \mathrm{cfu} / \mathrm{g}\right)$ were applied. Glomus was only applied 1 month after planting, whereas the tea and Bacillus were applied at planting and after 1 month. The extrusion procedure of twin-screw-extruder [Model MSZK B90e (Lehman Maschinenbau $\mathrm{GmbH}$, Jocketa, Germany)] for five month aged chipped olive branch pruning was explained in detail in a publication released in 2021 [17] (Dittrich, 2021).

The compost (COMP) was made from 70\% (by volume) chipped olive branch prunings, $10 \%\left(\mathrm{v} . \mathrm{v}^{-1}\right)$ chipped medicinal and aromatic plant residues $18 \%\left(\mathrm{v} . \mathrm{v}^{-1}\right)$ freshly cut grass from a lawn at ORI and $2 \%$ horse manure was applied as an activator to facilitate initiation of self-heating and aerobic decomposition by microorganisms. The compost windrow was set up in April-2021. After 2 months, a Trichoderma fungus isolated from forest soil was added. Application of the Trichoderma was conducted by a motorized back sprayer (1.2 mm drop diameter) after 2 months of composting. Green mycelium indicating occurrence of the Tricoderma was observed on $25^{\text {th }}$ April 2019, showing that the inoculation was successful. On 23rd May 2019, the first Coprinus sp. mushrooms were found on the compost. Coprinus spp. species are known as cellulose enzyme producing fungi. During 24-27th September 2019, isolated bacteria from a free-range goat stomach were isolated and applied to the windrow as described for Trichoderma. The goat stomach bacteria and Trichoderma species have cellulase enzymes, which are known to be beneficial for achieving a mature compost. Coprinus spp. species can also produce cellulose enzymes [18, 19, 20] (Rai et al., 1989; Seo et al., 2013; Liu et al., 2019). When composting process completely finalised (this means temperature reduced) passed through a 2-5 mm sieve before application.

The following analyses were performed on all of the media (PEAT+, COMP, FIBRE) treatments at the initial stage and after 12 months: pH [21] (TS 9104, TSI, 1991), electrical conductivity (EC) [22] (TSE, 9106, TSE, 1991), organic matter [23] (TS 9103, TSE, 1991). Total nitrogen (N) was determined by Dumas Method [24] (McGeehan and Naylor, 1988). Samples were digested with hydrogen peroxide $\left(\mathrm{H}_{2} \mathrm{O}_{2}\right)$ and nitric acid $\left(\mathrm{HNO}_{3}\right)$ in a microwave oven, before determination of phosphorus $(\mathrm{P})$, potassium $(\mathrm{K})$, calcium $(\mathrm{Ca})$, magnesium $(\mathrm{Mg})$, iron $(\mathrm{Fe})$, copper $(\mathrm{Cu})$, manganese $(\mathrm{Mn})$, zinc $(\mathrm{Zn})$, and boron $(\mathrm{B})$ in the filtrate with ICP-OES [25] (Zarcinas et al., 1987). In contrast, for the SAND samples, pH (1:2.5 soil/water)and electrical conductivity [26] (EC, McLean, 1982) were measures as well as lime (Scheibler calcimeter), [27] (Caglar, 1949); organic matter (Walkley-Black method) [28] (Jackson, 1962), total-N (Dumas); Olsen-P (0.5 M NaHCO3 pH: 8.5; [29] (Olsen et al. 1954), ammonium-acetatete extractable $\mathrm{K}, \mathrm{Ca}$, and $\mathrm{Mg}$; DTPA (diethylenetriamine pentaacetic acid)-extractable Fe, Cu, Mn, Zn [30] (Lindsay and Norvell 1978); and B extracted by 0.01 M mannitol + 0.01 M calcium chloride [31] (Kacar and Fox, 1966). Analysis of the physical characteristics; bulk density (picnometric) [32] (Blake and Hartge, 1986), water 
holding capacity [33] (U.S. Salinity Lab. Staff, 1954), easily available water and water buffering capacity [34] (Puustjarvi, 1969), air capacity [33, 35] (U.S.Salinity Lab. 1954, De Boodt et al., 1973), and particle density [36] (Sheldrick and Wang, 1993) .

The pots were irrigated regularly by application to each pot of a volume of water calculated to provide 50\% of moisture of each substrate (FIBRE: $400 \mathrm{ml} /$ week, COMP: 400 ml/week, SAND: 800 ml/week, PEAT+: 500 ml/week). Following the data moisture-meter (Reotemp) irrigation frequency of the different treatments was applied. While FIBRE irrigation intervals of application were usually less than once a week, for the SAND treatment the irrigation frequency was the highestat 2 times a week.

The statistical analysis was carried out with the software SAS (2007) JMP ${ }^{\odot}$, Version 7 (SAS Institute, Cary, NC, USA) [37] [SAS, 2007]. A two-factor hierarchical analysis of variance with inequality of variance for treatments between the samples of trial were carried out. Statistical differences between mean values were determined using T-Students and Tukey's significant difference test at $P<0.05$. A correlation matrix correlation coefficient was used to understand the relationships among the investigated parameters. Also, multiple pairwise comparisons of treatments for all materials were conducted as well as multiple pairwise comparisons within one sample for different sample settings.

\subsection{Pepper Trial (24-month, 2- season) Method}

The trial was carried out under certified organic experimental open fields of the Institution. The locations were in Menemen ( $1^{\text {st }}$ season) and in Tire ( $2^{\text {nd }}$ season) (Izmir, Turkey). This paper describes the two summer seasons of the growing period of the pepper (Capsicum annuum L., cv. Yalova Yaglik-28), from April 2019 to October 2020 in Mediterranean Climatic conditions. The organic seed of the 'Yalova Yaglik-28' standard variety was used to produce seedlings as the transplants in the Institute.

The trial was conducted using a factorial randomised plot design with 4 replications and 6 treatments. Factors were compost used (COMP+) and non-compost used (COMP-). Each replicate was composed of 6 plots and hence there was a total of 48 plots ( 2 factors $x$ 4 replications $\times 6$ treatments). Totally, 80 plants made up each plot $(5 \mathrm{~m} \times(70 \mathrm{~cm} \times \sim 30$ $\mathrm{cm})$ ) for two years in rotation with cabbage (Brassica oleracea L.) crop.

To determine the fertilizer to be applied quantity (Table ?) two parameters were taken as the base;

- The nitrogen content of the soil in the experimental locations

- The nitrogen content of the compost to be used in COMP+ site and

- pepper crop nitrogen demand

Each experimental plot soil was monitored seasonally and soil samples were collected;

(a) before planting and (b) after the last harvest)

The sampling of the soils of 0-30 $\mathrm{cm}$ was performed in 2 depths in both factorial designed 48 plots, separately;

A: $0-15 \mathrm{~cm}$ (This was sampled as A1:0-5cm and A2:5-15cm in each plot to perform phthalate analysis which has not given in this article).

B: $15-30 \mathrm{~cm}$

Compost was applied only to the COMP+ (factor 1 ) (for composting process of the COMP please see "olive sapling pot trial part") plots 15 days before plantation into the

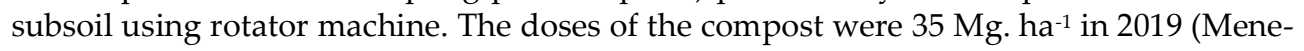
men Province) and $45 \mathrm{Mg}$ ha $^{-1}$ in 2020 (Tire Province).

During the vegetation periods of pepper $\left(15^{\text {th }}\right.$ April- $15^{\text {th }}$ October $)$ the applied "drip irrigation" water was determined as $392 \mathrm{~mm}$ in 2019 (Menemen). However, because of pandemic conditions in 2020 "furrow irrigation" was applied in Tire Province of Izmir (Turkey) and $648 \mathrm{~mm}$ irrigation water was measured. 
Table X. Commercial Fertilisation programme of COPM+ and COMP- in pepper trial sites.

\begin{tabular}{|c|c|c|c|}
\hline $\begin{array}{c}\text { Application } \\
\text { area of } \\
\text { Fertiliser }\end{array}$ & Year & Season & $\begin{array}{c}\text { Content of Applied Certified Organic } \\
\text { Commercial Fertilisers* }\end{array}$ \\
\hline $\begin{array}{c}\text { Soil } \\
\text { Menemen site }\end{array}$ & 2019 & Early April & 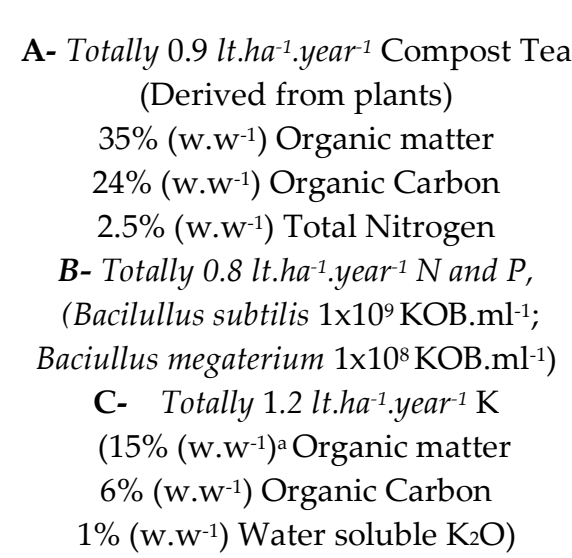 \\
\hline $\begin{array}{l}\text { Soil } \\
\text { Tire site }\end{array}$ & 2020 & Late April & 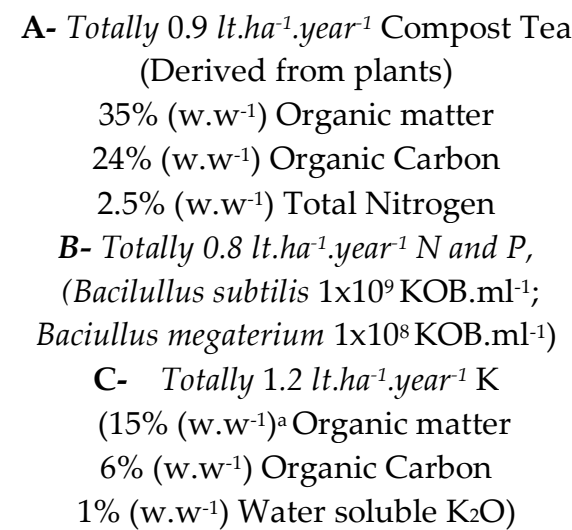 \\
\hline
\end{tabular}

* Organically Certified, liquid, in the IFOAM and OMRI list and local production.

Irrigation was applied as field water capacity reduced $50 \pm 5 \%$ in the soils $(0-30)$ of the trial sites. Cultural practices were implemented for prevention of pest occurred, but it was not reached economic threshold in both years. No any disease incidence was observed in both growth seasons. Weed control was performed manually and monthly weed suppression observation data was recorded which is not given in this article. The soil temperature and moisture content were also recorded 2 times a month in each plot.

The mulch material used to compare in the trials were produced in Poland (CUT, Czestochowa University of Technology, Faculty of Mechanical Engineering and Computer Science) and sent to Turkey (ORI, Izmir, Turkey) to be used in the experiments under the framework of the Organic-PLUS Project (GA 774349).

The initial and after last harvest of the pepper plots, soil was sampled $(0-30 \mathrm{~cm} ; \mathrm{A}: 0-$ $15 \mathrm{~cm}$ and B: $15-30 \mathrm{~cm}$ ) in each plot analysis were performed according to [38, 39, 40, 41, 42, 43, 44] [Kellogg (1952); Evliya (1964); Akalan (1965); Loue (1968); Olsen and Dean (1965); Pizer (1967); Follet and Lindsay (1970)]. Soil total organic carbon (SOC) was determined by a modified Walkley-Black procedure as described by [45] Nelson and Sommers (1982). Cation exchange capacity (CEC) (soil cation adsorption capacity) [46] (Soil Survey Staff, 1975), OMEI (organic matter stability efficiency index: maximum value 1) [47] 
(Adani et al. 1997), and the biological stability of compost expressed as the oxygen uptake rate (OUR = mg O2 kg OM-1 h-1) were also determined [48] (Adani et al. 2004).

The statistical analysis was carried out with the software SAS (2007) JMP ${ }^{\odot}$, Version 7 (SAS Institute, Cary, NC, USA) [37] [SAS, 2007]. A two-factor hierarchical analysis of variance with inequality of variance for treatments between the samples of trial were carried out. Statistical differences between mean values were determined using T-Students and Tukey's significant difference test at $P<0.05$. A correlation matrix correlation coefficient was used to understand the relationships among the investigated parameters. Also, multiple pairwise comparisons of treatments for all materials were conducted as well as multiple pairwise comparisons within one sample for different sample settings.

The following treatments were compared in the pepper trial:

1) C (Control (weeded))

2) $\mathrm{CNW}$ (Control (non - weeded))

3) $\mathbf{P}$ (Plastic mulch (petroleum sourced))

4) CUT 1 (Biodegradable mulch No:1)

5) CUT 2 (Biodegradable mulch No:2, In Menemen Province, $1^{\text {st }}$ season) (In Tire Province, $2^{\text {nd }}$ season: CUT 3 (Biodegradable mulch No:3))

6) OP (Chipped Olive branch pruning (thickness on the soil surface: $5 \mathrm{~cm}$ ))

Field plan of the pepper trials is as follows in Menemen (2019) and Tire (2020) Provinces:

\begin{tabular}{|c|c|c|c|}
\hline Replication & $\begin{array}{c}\text { Plot No/ } \\
\text { Abbrevation of the } \\
\text { treatment }\end{array}$ & Replication & $\begin{array}{c}\text { Plot No/ } \\
\text { Abbrevation of the } \\
\text { treatment }\end{array}$ \\
\hline II & $7 / \mathrm{C}$ & $\mathrm{I}$ & $1 / \mathrm{CNW}$ \\
\hline II & $8 / \mathrm{CNW}$ & $\mathrm{I}$ & $2 / \mathrm{OP}$ \\
\hline II & $9 / \mathrm{P}$ & $\mathrm{I}$ & $3 / \mathrm{P}$ \\
\hline II & $10 / \mathrm{OP}$ & $\mathrm{I}$ & $4 / \mathrm{CUT} 2$ \\
\hline II & $11 / \mathrm{CUT} 1$ & $\mathrm{I}$ & $5 / \mathrm{C}$ \\
\hline II & $12 / \mathrm{CUT} 2$ & $\mathrm{I}$ & $6 / \mathrm{CUT} 1$ \\
\hline IV & $19 / \mathrm{CNW}$ & $\mathrm{III}$ & $13 / \mathrm{CUT} 2$ \\
\hline IV & $20 / \mathrm{CUT} 1$ & $\mathrm{III}$ & $14 / \mathrm{CUT} 1$ \\
\hline IV & $21 / \mathrm{CUT} 2$ & $\mathrm{III}$ & $15 / \mathrm{OP}$ \\
\hline IV & $22 / \mathrm{OP}$ & $\mathrm{III}$ & $16 / \mathrm{CNW}$ \\
\hline IV & $23 / \mathrm{C}$ & $\mathrm{III}$ & $17 / \mathrm{P}$ \\
\hline IV & $24 / \mathrm{P}$ & $\mathrm{III}$ & $18 / \mathrm{C}$ \\
\hline
\end{tabular}

\section{Results}

\subsection{Compost Results}

The results of stabile compost physical, physiochemical and chemical analysis were presented in 6-month pot trial evaluation released in a publication in 2021 [3] (Kir et al., 2021) except TOC, $\mathrm{NH}_{4}-\mathrm{N}, \mathrm{NO}_{3}-\mathrm{N}, \mathrm{CEC}$, OUR, and IMEI Table ?. The compost quality was found compatible with the local and international legislations. When the composting was initiated by irrigation on $15^{\text {th }}$ April 2020 the material C: $\mathrm{N}$ ratio was calculated as 36.5 : 
1, but after 8-month process, the compost was a black-dark brown coloured, easily dispersed material and the smell was like "Geosmin". Initial materials used and the method for composting significantly influence the nutritional quality and $\mathrm{C}$ : $\mathrm{N}$ ratio; so that the maturation was verified by C: $\mathrm{N}$ ratio [49] (US Composting Council, 1997; [50] Kirchmann and Witter, 1989) which was determined as 12.3: 1. The maximum measurement of the compost temperature was recorded as $48^{\circ} \mathrm{C}$ within the first 15 days of composting and $72{ }^{\circ} \mathrm{C}$ in 34 days in the core point of the pile. Moreover, IMEI with its close figure to 1 showed that the compost is stable [47] (Adani et al., 1997).

Table X. Physical and chemical analysis of the COMP (Initial) in dry matter.

\begin{tabular}{|c|c|c|c|}
\hline Parameter & COMP (Initial) & Parameter & COMP (Initial) \\
\hline Moisture (\%) & 39.4 & $\mathrm{Ca}(\%)$ & 2.9 \\
\hline $\mathrm{pH}$ & 8.2 & $\operatorname{Mg}(\%)$ & 0.4 \\
\hline $\mathrm{EC}(\mu \mathrm{S} / \mathrm{cm})$ & 570 & $\mathrm{Fe}(\mathrm{ppm})$ & 8132 \\
\hline $\mathrm{OM}(\%)$ & 58 & Mn (ppm) & 332.8 \\
\hline $\mathrm{C}(\%)$ & 26.9 & $\mathrm{Zn}(\mathrm{ppm})$ & 89.6 \\
\hline TOC $\left(\mathrm{g}^{\mathrm{kg}} \mathrm{kg}^{-1}\right)$ & 189.7 & $\mathrm{Cu}(\mathrm{ppm})$ & 28.7 \\
\hline $\mathrm{N}(\%)$ & 2.2 & $\mathrm{~B}(\mathrm{ppm})$ & 43.7 \\
\hline $\mathrm{NH}_{4}-\mathrm{N}(\%)$ & 0.6 & $\mathrm{Na}(\mathrm{ppm})$ & 280 \\
\hline $\mathrm{NO}_{3}-\mathrm{N}(\%)$ & 0.7 & Mo (ppm) & 0.9 \\
\hline $\mathrm{C} / \mathrm{N}$ & 12.3 & $\mathrm{Cd}(\mathrm{ppm})$ & 0.3 \\
\hline OUR $\left(\mathrm{mg} \mathrm{O}_{2} \mathrm{~kg} \mathrm{OM}^{-1} \mathrm{ha}^{-1}\right)$ & 350 & Co (ppm) & 4.1 \\
\hline IMEI & 0.8 & $\mathrm{Cr}(\mathrm{ppm})$ & 51.6 \\
\hline CEC (me.100 $\left.\mathrm{g}^{-1}\right)$ & 0.1 & $\mathrm{Ni}(\mathrm{ppm})$ & 28.2 \\
\hline $\mathrm{P}(\%)$ & 0.1 & $\mathrm{~Pb}(\mathrm{ppm})$ & 7.9 \\
\hline $\mathrm{K}(\%)$ & 1.4 & $\mathrm{Al}(\mathrm{ppm})$ & 12936 \\
\hline
\end{tabular}

Physical characteristics; bulk density (picnometric), water holding capacity, easily available water and water buffering capacity, air capacity, and particle density were reported in the 3 Kir et al.,2021. According to results, compost physical quality found as good as peat.

\subsection{Olive Sapling Pot Trial (12 month) Results}

The results presented in Table? Compost was found the best in LAR, NR, and NLB vegetative parameters. Additionally, compost also was determined in the same group with PEAT+ in NMB, MBL, DRW. The result about the LTR showed that FIBRE was the best, while its density in the same group with COMP.

\subsection{Pepper Trial (24-month, 2- season)) Results}

In the experiment the application rate of $\mathrm{N}$ did not exceed $170 \mathrm{~kg} \mathrm{ha}^{-1}$. year-1 in the soil of the sites while the pepper $\mathrm{N}$ demand higher than that limit in many publications. The soil initial physical and chemical parameters were showed in Table?. It can be stated that the locations resembling one an another and not have a great difference were determined in terms of soil nutritional structure. According to climatic conditions, Menemen and Tire Provinces of Izmir temperature and humidity almost same in 2019 and 2020. 
Table X. Statistically different vegetative parameters of the 12-month olive sapling pot trial (2019-2020).

\begin{tabular}{|c|c|c|c|c|c|c|c|c|c|c|}
\hline Treatment & $\begin{array}{c}\text { Plant } \\
\text { height } \\
(\mathrm{PH})(\mathrm{cm})\end{array}$ & $\begin{array}{l}\text { Number } \\
\text { of main } \\
\text { branches } \\
\text { per plant } \\
(\mathrm{NMB})^{*}\end{array}$ & $\begin{array}{l}\text { Number } \\
\text { of lateral } \\
\text { branches } \\
\text { per plant } \\
(\mathrm{NLB})^{*}\end{array}$ & $\begin{array}{l}\text { Main } \\
\text { Branch } \\
\text { length } \\
\text { (MBL) } \\
\text { (cm)* }\end{array}$ & $\begin{array}{c}\text { Fresh } \\
\text { Plant } \\
\text { volume } \\
\text { (FPV) } \\
(\mathrm{cm} 3)^{*}\end{array}$ & $\begin{array}{c}\text { Dried root } \\
\text { weight } \\
\text { (DRW) } \\
\text { (g)* }\end{array}$ & $\begin{array}{l}\text { Number } \\
\text { of roots } \\
(\mathrm{NR})^{*}\end{array}$ & $\begin{array}{l}\text { Length of } \\
\text { architecture } \\
\text { (density) } \\
\text { root } \\
\text { (LAR) }(\mathrm{cm})^{*}\end{array}$ & $\begin{array}{c}\text { Dried } \\
\text { plant } \\
\text { weight } \\
\text { (DPW) } \\
\text { (g)* }\end{array}$ & $\begin{array}{c}\text { Length } \\
\text { of total } \\
\text { root } \\
\text { (LTR) } \\
\text { (cm) }\end{array}$ \\
\hline FIBRE & $30.23 \mathrm{C}$ & $2.00 \mathrm{~B}$ & $4.13 \mathrm{~B}$ & 17.17 B & $370.10 \mathrm{C}$ & $14.40 \mathrm{~B}$ & $33.47 \mathrm{AB}$ & $4.50 \mathrm{AB}$ & $22.67 \mathrm{~B}$ & $25.18 \mathrm{~A}$ \\
\hline COMP & $35.70 \mathrm{~B}$ & $2.13 \mathrm{AB}$ & $8.76 \mathrm{~A}$ & $19.47 \mathrm{AB}$ & $707.61 \mathrm{~B}$ & $15.00 \mathrm{AB}$ & $36.21 \mathrm{~A}$ & $4.84 \mathrm{~A}$ & $\begin{array}{c}28.75 \\
\mathrm{AB}\end{array}$ & $16.93 \mathrm{~B}$ \\
\hline PEAT+ & $42.70 \mathrm{~A}$ & $2.58 \mathrm{~A}$ & $7.33 \mathrm{~A}$ & $23.81 \mathrm{~A}$ & $1028.56 \mathrm{~A}$ & $15.38 \mathrm{AB}$ & $30.75 \mathrm{C}$ & $3.73 \mathrm{~B}$ & $\begin{array}{c}29.63 \\
\mathrm{AB}\end{array}$ & $12.37 \mathrm{C}$ \\
\hline SAND & $34.33 \mathrm{BC}$ & $2.33 \mathrm{AB}$ & $5.17 \mathrm{~B}$ & $18.31 \mathrm{~B}$ & 556.52 B & $20.00 \mathrm{~A}$ & $27.50 \mathrm{C}$ & $3.75 \mathrm{~B}$ & $31.87 \mathrm{~A}$ & $17.40 \mathrm{~B}$ \\
\hline $\operatorname{CV}(5 \%)$ & 19.67 & 3.95 & 11.68 & 12.39 & 18.99 & 12.84 & 13.10 & 6.18 & 13.59 & 18.65 \\
\hline
\end{tabular}

*Square root transformation was applied.

Table X. Initial soil $(0-30 \mathrm{~cm})$ physical and chemical parameter results in dry matter (DM) in the locations.

\begin{tabular}{|c|c|c|c|c|c|c|}
\hline \multirow{2}{*}{$\begin{array}{c}\text { Parameter (DM) } \\
\text { Soil depth }\end{array}$} & \multicolumn{3}{|c|}{$\begin{array}{c}2019 \\
\text { Menemen site }\end{array}$} & \multicolumn{3}{|c|}{$\begin{array}{c}2020 \\
\text { Tire site } \\
\end{array}$} \\
\hline & Evaluation & $0-15 \mathrm{~cm}$ & $15-30 \mathrm{~cm}$ & Evaluation & $0-15 \mathrm{~cm}$ & $15-30 \mathrm{~cm}$ \\
\hline Texture & Loamy & Loamy & Loamy & Loamy & Loamy & Loamy \\
\hline $\mathrm{pH}$ & Slightly alkaline & 7.63 & 7.67 & Notr & 6.90 & 6.93 \\
\hline $\mathrm{EC}\left(\mathrm{mS} . \mathrm{cm}^{-1}\right)$ & No risk & 0.46 & 0.47 & No risk & 0.28 & 0.28 \\
\hline $\mathrm{CaCO}_{3}(\%)$ & Limy & 4.73 & 4.80 & Low & 1.83 & 1.87 \\
\hline $\mathrm{OM}(\%)$ & Low & 1.73 & 1.65 & Low & 1.18 & 1.01 \\
\hline Total N (\%) & Very Low & 0.05 & 0.05 & Very Low & 0.09 & 0.07 \\
\hline TOC (Mg.ha-1) & Low & 14.91 & 10.26 & Low & 18.56 & 13.79 \\
\hline (Available) $\mathrm{P}_{2} \mathrm{O}_{5}\left(\mathrm{mg} \cdot \mathrm{kg}^{-1}\right)$ & Very Low & 2.61 & 2.50 & Low & 3.13 & 3.06 \\
\hline Available K (mg.kg-1) & Low & 195.93 & 193.00 & Very Low & 44.64 & 42.21 \\
\hline Available Ca (mg.kg-1) & Very High & 4447.30 & 4465.60 & Medium & 2283.36 & 2190.30 \\
\hline Available Na (mg.kg-1) & Low & 57.64 & 49.50 & Low & 33.29 & 41.29 \\
\hline Available Mg (mg.kg-1) & High & 280.75 & 289.10 & High & 307.02 & 308.34 \\
\hline Available Fe (mg.kg-1) & Low & 1.98 & 2.05 & Sufficient & 16.57 & 17.51 \\
\hline Available Mn (mg.kg-1) & Sufficient & 6.85 & 6.88 & Sufficient & 6.37 & 7.75 \\
\hline Available Zn (mg.kg-1) & Low & 0.33 & 0.27 & Low & 0.38 & 0.43 \\
\hline Available Cu (mg.kg-1) & Sufficient & 2.90 & 3.20 & Sufficient & 0.96 & 0.98 \\
\hline Available B (mg.kg-1) & Sufficient & 1.68 & 1.67 & Sufficient & 1.14 & 1.06 \\
\hline
\end{tabular}

\footnotetext{
${ }^{*}$ Average of the replications.
} 
Compost application (COMP+) in pepper production has increased total organic matter and soil organic carbon, significantly $(\mathrm{p}<0.05)$ as compared to not any local compost used plots (COMP-) in those two locations. Furthermore, average total organic matter content increase was obtained approximately " 0.5 " higher than in COM+ factor's OP treatment plots in both locations.

In the experiments, the difference of SOM and SOC between the composted (COMP+) and non-composted (COMP-) factors and each treatment (different mulch materials) was searched by applying the paired t-test Table ??.. The SOM and SOC were correlated well with pepper yields of COMP+ factor showed in Table ??.; however, the results not found as high correlated as COMP-. The min and maximum SOC content of the experiments were ranged between $8.96 \mathrm{M}$

Table X. Soil (A: 0-15 cm) average SOM and SOC parameter paired t test results in between the COMP+ (compost applied) and COMP- (compost not applied) in the locations.

\begin{tabular}{cccc}
\hline Locations & Treatments & SOM (0-15 cm) & SOC (0-15 cm) \\
\hline Menemen(2019) & C & 0.22 & 0.16 \\
\hline & CNW & 0.36 & 0.23 \\
\hline & P & $0.58^{*}$ & $0.38^{*}$ \\
\hline & CUT1 & $0.59^{*}$ & $0.42^{*}$ \\
\hline & CUT2 & $0.62^{*}$ & $0.54^{*}$ \\
\hline Tire (2020) & OP & $0.89^{*}$ & $0.61^{*}$ \\
\hline & C & 0.18 & 0.13 \\
\hline CNW & 0.30 & 0.20 \\
\hline & P & $0.43^{*}$ & $0.35^{*}$ \\
\hline & CUT1 & $0.50^{*}$ & $0.40^{*}$ \\
\hline & CUT3 & $0.69^{*}$ & $0.54^{*}$ \\
\hline
\end{tabular}

*Significantly important at $\mathrm{p}<0.05$ level

Table X. Pepper yield correlations with SOM and SOC in the COMP+ in Menemen (2019) and Tire (2020).

\begin{tabular}{ccccc}
\hline Factor & Locations & Treatments & \multicolumn{2}{c}{ Pepper yield correlation } \\
\hline & & & SOM & SOC \\
\hline COMP+ & Menemen (2019) & C & 0.24 & 0.29 \\
\hline & CNW & 0.16 & 0.19 \\
\hline & P & 0.38 & 0.24 \\
\hline & CUT1 & $0.78^{*}$ & $0.68^{*}$ \\
\hline & CUT2 & 0.51 & 0.42 \\
\hline & OP & $0.89^{*}$ & $0.88^{*}$ \\
\hline
\end{tabular}




\begin{tabular}{cccc}
\hline Tire (2020) & C & 0.10 & 0.21 \\
\hline & CNW & 0.12 & 0.15 \\
\hline P & $0.57^{*}$ & $0.66^{*}$ \\
\hline CUT1 & $0.59^{*}$ & $0.63^{*}$ \\
\hline CUT3 & $0.87^{*}$ & $0.88^{*}$ \\
\hline OP & $0.91^{*}$ & $0.85^{*}$ \\
\hline
\end{tabular}

*Significantly important at $\mathrm{p}<0.05$ level

\section{Discussion}

\subsection{Compost}

According to the FAO [51], agricultural greenhouse gas emissions will increase by $4 \%$ by 2030 , with more than $80 \%$ of this increase coming from animal husbandry, increasing the trend towards plant-based alternatives to reduce the carbon footprint. Reducing food loss and waste through a consistent set of policies and investments in food production, harvesting, handling, packaging, storage, transportation, processing and marketing has been identified by FAO as one of the key policy areas to enable food supply chains to reduce the cost of nutritious food. Authors should discuss the results and how they can be interpreted from the perspective of previous studies and of the working hypotheses. The findings and their implications should be discussed in the broadest context possible. Future research directions may also be highlighted.

Moreover, according to the VMR https://www.verifiedmarketresearch.com/ report [52], the global vegan fast food market size was valued at $\$ 17$ billion in 2020, expected to reach $\$ 40.3$ billion by 2028 and $11.4 \%$ between 2021 and 2028. Additionally, plant based and agro-industrial waste reduction and recycling them by composting has rising interest worldwide.

Considering above mentioned topics, in this study the lignocellulose based compost effects were investigated. The proportion of the horse manure minimized as $2 \%$. However, the interest should be given more deeply to phase out "manure" from initial materials in composting in the near future. The "totally plant sourced compost" might be one of the soil fertility and plant nutrition product to produce organic crops to supply "Vegan organic market rising demand". Thus, concerning with "vegan" organic production and plant nutritional inputs may be the target and a fruitful market of the possible developing countries such as Turkey. On the other hand, olive tree pruning material is at the enormous amount in the country to be recycled by composting. These plant garbage is not using any industry and may be the biggest problem of the farmers to be get rid of them in terms of labor cost, because prune of the trees should be done in every 2-year-intervals most of the olive varieties in Turkey. For this reason, tree pruning residuals have incinerated in many countries in Mediterranean Region which is pollutant source of carbon dioxide in air and detrimental for soil biodiversity according to many publications.

\subsection{Olive Sapling Pot Trial (12 month)}

The compost successful capability as a growing media in olive saplings as we compared to peat and sand based substrates can be attributed the stability and maturity properties of the on farm compost. 


\subsection{Pepper Trial (24-month, 2-season))}

Pepper grown in soil amended with compost exhibited a higher SOC content than plants cropped in not on farm compost soil. Similarly, [53], Flisc et al., 2009 reported that green compost SOC content (in kg per t) (fresh substance) is 214, whereas composted manure's

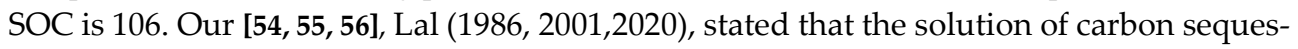
tration can be achieved as we incorporate $2 \%$ carbon into the terrestrial sites, because "compost" is carbon rich material when it is considered possible initiatives showed in Table?

Table X. C/N ratios of some organic materials

\begin{tabular}{lll}
\hline Type of waste & $\mathbf{C / N}$ & Source \\
\hline Grass Clippings & $9-25$ & [57] (Rynk, 1992) \\
& $12-15$ & [58] (Diaz et al., 1993) \\
& 19 & {$[59]$ (Gotaas, 1956) } \\
\hline Leaf (green) & 41 & [60] (Haug, 1993) \\
\hline Leaf (dry) & $40-80$ & [57] (Rynk,1992) \\
\hline Kitchen waste & $14-16$ & [57] (Rynk, 1992) \\
\hline Mixed domestic waste & $13-31$ & [61] (Epstein, 1997) \\
\hline Sawdust & $200-500$ & [58] (Diaz et al.,1993) \\
& $200-750$ & [57] (Rynk,1992) \\
& 85 & [62] (Sussman,1984) \\
\hline
\end{tabular}

Thus, carbon rich material containing compost may show and influence to establishment of strong correlations between pepper yield and SOC.

\section{Conclusions}

There are increasing concerns about peat and animal manure replacement with plant based inputs in ecological production in Europe. Among possible alternative markets the organic "vegan products" could be a way of trade for developing countries such as Turkey. The improvement of the country's export in relation with enhancing plant based garbage recycling to obtain co-compost may be contributing in organic movements. In this study, mature and stable compost influenced on SOM, SOC in pepper (Capsicum annuum L.) trial and vegetative parameters in olive (Olea europaea L) sapling pot trial, positively, which means reducing carbon release to air.

Stable and mature on-farm produced green compost which is made up of $98 \%$ plant residues has capacity to increase crop yield and quality under organic management, as it is used regularly and in a long-term application preferable. However, increasing concerns on the quality compost replacement of peat in horticultural seedlings and saplings need further research in every crop species. Additionally, it can be assumed that rising attention 
is expected to be given soil organic matter building methods in agricultural soils in relation to soil organic carbon sequestration and climate change mitigation. It is concluded that using of non-fertilized compost as a substrate was resulted to the best root development of olive saplings as it is compared to commercial $40 \%$ peat, commercial sand, and fibre after a year from the saplings planted into the pots. The shortened and low ammonium volatilization promoted composting procedure should be investigated, furtherly.

It is also concluded that SOC controlled by carbon rich material such as compost and fresh chipped pruning material amendment to agricultural soils. However, challenges have still remain concerning the composting procedure which release ammonium gas to the air needed long period of time as 8-month period, even if it is better than 2-year time period, in "on-farm pile composting method", the study demonstrated that mature and lignocellulose based compost application as a soil conditioner support and capacity to the reduced harmful gases release, especially carbon dioxide which has much more proportion as compared the rest of the greenhouses, in the atmosphere on earth. Fractions of the SOC should be investigated in different doses of compost application under organic management to widen the insight of the issues.

Funding: This research was funded by EU Horizon2020, ORGANIC-PLUS project, grant number 774340.

Data Availability Statement: Data supporting reported results can be found in deliverable reports of the ORGANIC PLUS project, grant number 774340 presented to EU Commission.

Acknowledgments: 1-The author is grateful for the kind assistance of organic experimental farm management of the sites in Menemen and Tire Provinces (Izmir, Turkey) and labours of the Ministry of Agriculture and Forestry, Olive Research Institute for their efforts in Covid-19 pandemic conditions. 2- Following publication stated first 6-month results of the substrates was received the best oral presentation award (Volaco) in Growing Media2021 Symposium of ISHS: Kir, A., Løes, A.K., Cetinel, B., Turan, H.S., Aydogdu, E., Pecenka, R., Dittrich, C., Cáceres, R., Lennartsson Turner, M., Rayns, F., Conroy, J. and Schmutz, U. (2021). Testing peatfree growing media based on olive wood residues for olive saplings. Acta Hortic. 1317, 23-32 DOI: 10.17660/ActaHortic.2021.1317.4

Conflicts of Interest: The authors declare no conflict of interest. The funders had no role in the design of the study; in the collection, analyses, or interpretation of data; in the writing of the manuscript, or in the decision to publish the results.

\section{References}

1. Fuchs JG, Berner A, Mayer J, Smidt E, Schleiss K. (2008). Influence of compost and digestates on plant growth and health: potentials and limits. Pages 101-110 in J.G. Fuchs TK, L. Tamm, K. Schenk, ed. CODIS 2008: Compost and digestate: sustainability, benefits, impacts for the environment and for plant production. Solothurn, Switzerland: FiBL, Research Institute of Organic Agriculture, Frick, Switzerland.

2. Makas, M.; Windeisen, E.; andWegener, G. (2000). Substitution von Torf durch Holz in Pflanzsubstraten. European Journal of Wood and Wood Products 2000, 58, 125-126.

3. Kir, A., Løes, A.K., Cetinel, B., Turan, H.S., Aydogdu, E., Pecenka, R., Dittrich, C., Cáceres, R., Lennartsson Turner, M., Rayns, F., Conroy, J. and Schmutz, U. (2021). Testing peatfree growing media based on olive wood residues for olive saplings. Acta H ortic. 1317, 23-32 DOI: 10.17660/ActaHortic.2021.1317.4

4. Koopmans, C.J. and Zanen, M. (2007) Organic Soil Management: Impacts on Yields, Soil Quality and Economics. Paper at: 3rd QLIF Congress: Improving Sustainability in Organic and Low Input Food Production Systems, University of Hohenheim, Germany, March 20-23, 2007

5. Alburquerque, J.A., C. de la Fuente, A. Ferrer-Costa, L. Carrasco, J. Cegarra, M. Abad and M. Pilar Bernal. (2012). Assessment of the fertiliser potential of digestates from farm and agroindustrial residues. Biomass and Bioenergy (40) 181-189.

6. Gruda, N.S. Increasing sustainability of growing media constituents and stand-alone substrates in soilless culture systems. Agronomy 2019, 9, 298.

7. Clark, Sean; Cavigelli, Michel (2005). Suitability of Composts as Potting Media for Production of Organic Vegetable Transplants. Compost Science \& Utilization, 13(2), 150-155. doi:10.1080/1065657X.2005.10702232 
8. Raviv M. (2015). Can the use of composts and other organic amendments in horticulture help to mitigate climate change? Acta Horticulture 1076: 19-28.

9. IPCC, 2021: Climate Change 2021: The Physical Science Basis. Contribution of Working Group I to the Sixth Assessment Report of the Intergovernmental Panel on Climate Change [Masson-Delmotte, V., P. Zhai, A. Pirani, S. L. Connors, C. Péan, S. Berger, N. Caud, Y. Chen, L. Goldfarb, M. I. Gomis, M. Huang, K. Leitzell, E. Lonnoy, J. B. R. Matthews, T. K. Maycock, T. Waterfield, O. Yelekçi, R. Yu and B. Zhou (eds.)]. Cambridge University Press. In Press.

10. Willer H, Schlatter B, Trávnícev J, Kemper L, Lernoud J. (Eds). FiBL \& IFOAM - Organics international: The world of organic agriculture. Statistics and emerging trends 2020. Research institute of organic agriculture FiBL and IFOAM - Organics international; 2020 Fev [cited 2020 Sep 04]. [333 p.]. Available from http://www.fao.org/agroecology/database/ detail/en/c/1262695/.

11. Cicek, G.; Sumer, S.; Egesel, C.; Say, S.; and Aydin, A. (2021). Determination of Coefficients and Biomass Potential for Pruning Residuals in Some Olive Varieties. Kahramanmaras Sutcu İmam University, Tarim ve Doga Dergisi, 24 (2), 313-318. DOI: 10.18016/ksutarimdoga.vi.690022

12. Anonymous, (2020), https://trendeconomy.com/data/commodity_h2/2703, 20.12.2020.

13. Bek, D.,Lennartsson Turner, M., Lanari. N., Conroy J. and Evans, A. 2020. Transitioning towards peatfree horticulture in the UK; an assessment of policy, progress, opportunities and barriers. Coventry University, Coventry. UK.

https://growingmedia.co.uk/research.html

14. Anonymous, (2021), https://www.theguardian.com/environment/2021/dec/18/peat-sales-to-gardeners-in-england-and-walesto-be-banned-by-2024, 11.11.2021.

15. Ozkaya, M., (1997).The effects of various treatments on anatomical and biochemical structures of cuttings, in some Olive (Olea europaea L.) Cultivars. Ankara University, Graduate School of Natural and Applied Sciences Department of Horticulture, Ph.D. Thesis, 1997, 136 pages, Ankara.

16. Ozkaya, M.T. and Celik, M. (1999).The Effects of Various Treatments on Endogenous Carbohydrate Content of Cuttings in Easy-To-Root and Hard-To-Root Olive Cultivars, Acta Hortic. 474, 51-54,

DOI: 10.17660/ActaHortic.1999.474.5, https://doi.org/10.17660/ActaHortic.1999.474.5

17. Dittrich, C.; Pecenka, R.; Løes, A.-K.; Cáceres, R.; Conroy, J.; Rayns, F.; Schmutz, U.; Kir, A.; Kruggel-Emden, H. Extrusion of Different Plants into Fibre for Peat Replacement in Growing Media: Adjustment of Parameters to Achieve Satisfactory Physical Fibre-Properties. Agronomy 2021, 11, 1185. https:// doi.org/10.3390/agronomy11061185

18. Rai, S. N., Walli, T. K., \& Gupta, B. N. (1989). The chemical composition and nutritive value of rice straw after treatment with urea or Coprinus fimetarius in a solid state fermentation system. Animal Feed Science and Technology, 26(1-2), 81-92.

19. Seo, J. K., Park, T. S., Kwon, I. H., Piao, M. Y., Lee, C. H., \& Ha, J. K. (2013). Characterization of Cellulolytic and Xylanolytic Enzymes of Bacillus licheniformis JK7 Isolated from the Rumen of a Native Korean Goat. Asian-Australasian journal of animal sciences, 26(1), 50-58, https://doi.org/10.5713/ajas.2012.12506

20. Liu, P., Lin, A., Zhang, G., Zhang, J., Chen, Y., Shen, T., ... \& Wang, W. (2019). Enhancement of cellulase production in Trichoderma reesei RUT-C30 by comparative genomic screening. Microbial cell factories, 18(1), 81.

21. TSE, 1991. Determination of Peat-pH (TS 9104), 3p.

22. TSE, 1991. Peat-EC Value and Determination of Salt Amount, (TS 9106), 3p.

23. TSE, 1991. Determination of Peat-Ash and Organic Matter, (TS 9103), 2p.

24. McGeehan, S.L. and Naylor, D.V., 1988. Automated Instrumental Analysis of Carbon and Nitrogen in Plant and Soil Samples. Journal of Comm. Soil Sci. Plant Anal., 19(4): 493-505.

25. Zarcinas, B. A., Cartwrigt, B. and Spauncer, L. P., 1987. Nitric Acid Digestion and Multielement Analysis of Plant Material by Inductively Coupled Plasma Spectrometry. Commun. Soil Sci. Plant Anal., 18:131-147.

26. Mclean, E. O., 1982. Soil pH and Lime Requirement in Methods of Soil Analysis (A. L. Page et al. editor). Part II, $2^{\text {nd }}$, American Society of Agronomy Inc. Publisher, Madison, Wisconsin, U.S.A., 199-224p.

27. Caglar, K. O., 1949. Soil Science, Ankara University Publications, No:10, Ankara, 68-72p.

28. Jackson, M. L., 1962. Soil Chemical Analysis. Prentice Hall Inc. Eng. Cliffs, Newyork, U.S.A., 183-187p.

29. Olsen, S. R., Cole, C. V., Watanabe, F. S. and Dean, H. C., 1954. Estimation of Available Phosphorus in Soils by Extraction with Sodium Bicarbonate. U.S. Dept. of Agr. Vir., Washington D.C., U.S.A., 139-141p.

30. Lindsay, W. L. and Norwell, W. A., 1978. Development of a DTPA Soil Test for Zinc, Iron, Manganese and Copper. Soil Science Society of America Journal, 42:421-428.

31. Kacar, B. and Fox, R. L., 1966. Boron Status of Some Turkish Soils. University of Ankara, Yearbook of The Faculty of Agriculture, Ankara, 9-11p.

32. Black, C.A., 1982. Methods of Soil Analiysis Part 2. Chemical and Microbiological Properties. Second Edition. American Society of Agro. İne. Medison VVisconsin. U.S.A.

33. U.S.Salinity Lab. Staff, 1954. Diagnosis and Improvement of Saline and Alkali Soils. Agric. Handbook No: 60; 160.

34. Puustjarvi, V., 1969. ftdng Peat Standarts. Peal-Plant Mevvs 2

35. De Boodt, M., O. Verdonck, 1. Capparet, 1973. Method for Measuring the Water Release Curve of Organic Substrates. Proceeding Symposium Artlfical Media in Horliculture. P: 2054- 2062.

36. Sheldrick, B.H. and Wang, C. (1993) Particle Size Analysis. In: Carter, M.R., Ed., Soil Sampling and Methods of Analysis, Lewis Publishers, Boca Raton, 499-517. 
37. SAS Institute Inc., (2007). SAS STAT Software, Release 2007 JMP ${ }^{\odot}$, Version 7, Cary, N.C., USA.

38. Kellogg, C.E., 1952. Our Gardens Soils. The Macmillan Company, New York, USA.

39. Evliya, H., 1964. Kültür Bitkilerinin Beslenmesi. Ankara Üniversitesi Ziraat Fakültesi Yayınları, Sayı: 36, Ankara, Türkiye.

40. Akalan, İ., 1965. Toprak (Oluşu, Yapısı ve Özellikleri). Ankara Üniversitesi Ziraat Fakültesi Yayınları, No: 241, Ders Kitabı: 80, Ankara Üniversitesi Basımevi, Ankara, Türkiye.

41. Loue, A., 1968. Diagnostic Pétiolairem de Prospection. Etudes Sur La Nutrition et La Fertilisation Potassiques de La Vigne. Sociéte Commerciale des Potasses d' Alsace Services Agronomiques, 31- 41p.

42. Olsen, S.R., and Dean, L.A., 1965. Phosphorus. Black C.A. (Editor), Methods of Soil Analysis. Part 2. American Society of Agronomy, Inc. Publisher Madison, Wisconsin, USA, 1035-1049p.

43. Pizer, N.H., 1967. Some Advisory Aspects. Soil Potassium and Magnesium. Tech. Bull. No: 14:184-186.

44. Follet, R. F., and Lindsay, W. L., 1970. Profilo Distribution of Zn, Fe, Mn and Cu in Colorado Soils, 78-82p

45. Nelson, D.W. and Sommer, L.E. (1982) Total Carbon, Organic Carbon and Organic Matter. Methods of Soil Analysis, Part 2. Chemical and Microbiological Properties, 2nd Edition. ASA-SSSA, Madison, 595-579.

46. Soil Survey Staff. 1975. Soil Taxonomy: A Basic System of Soil Classification for Making and İnterpreting Soil Surveys, USDASCS Agric. Handbook 436. U.S. Gov.Print Office, Washington, DC. Soil Survey Staff. 1975. Soil Taxonomy: A Basic System of Soil Classification for Making and İnterpreting Soil Surveys, USDA-SCS Agric. Handbook 436. U.S. Gov.Print Office, Washington, DC.

47. Adani, F., P.L. Genevini, F. Gasperi and G. Zorzi. 1997. Organic Matter Evolution Index (OMEI) as a measure of composting efficiency. Compost Sci. \& Util., 5:53-62.

48. Adani, F., R. Confalonieri and F. Tambone. 2004. Dynamic respiration index as descriptor of the biological stability of organic wastes. J. Environ. Qual., 33:1866-1876.

49. The U.S. Composting Council. 1997. Test methods for the examination of composting and compost, The U.S. Composting Council, Bethesda, Maryland USA.

50. Khirsmann, H. and Wtter E., 1989. Ammonnia volatilization during aerobic and anaerobic manure decomposition. Plant and Soil 115, 35-41.

51. FAO Report, 2019. FAO's work on Climate change, United Nations Climate Change Conference, 2019, 40p.

52. VMR Report, 2021. https://www.verifiedmarketresearch.com/, 28.12.2021

53. Flisc R, Sinaj S, Charles R, Richner W, (2009) GRUDAF 2009. Principles for fertilisation in arable and fodder production (in German). Agrarforschung 16, 1-100.

54. Lal, R. 1986. Soil surface management in the tropics for intensive land use and high and sustained productivity. In: Steward, B.A. (eds.), Improving Agriculture Production in the Tropics. Advances in Soil Science, Vol. 5. Springer, New York, pp. 245275.

55. Lal, R. 2001. World cropland soils as a source or sink for atmospheric carbon. Advances in Agronomy, 71:145-191

56. Lal, R., (2020). Eco-Intensification of Agroecosystems to Realize the Sustainable Development Goals of the United Nations. In: Sanjay-Swami, Kohli, A., Borah, N., De, S., Arora, S. and Singh, A.K. (Eds.) Souvenir cum abstract e-book, Resource Management and Biodiversity Conservation to Achieve Sustainable Development Goals, Academy of Natural Resource Conservation and Management, September 11- 12, 2020, Lucknow (U.P.), India, p 395.

57. Rynk, R. (1992) On-Farm Composting Handbook. Natural Resource, Agriculture, and Engineering Service, Ithaca, New York, $186 \mathrm{p}$.

58. Diaz, L..F, G.M. Savage, L.L. Eggerth, A. Chiumenti, Chapter 5 Systems used in composting, Editor(s): L.F. Diaz, M. de Bertoldi, W. Bidlingmaier, E. Stentiford, Waste Management Series, Elsevier, Volume 8, 2007, Pages 67-87, ISSN 1478-7482, ISBN 9780080439600, https://doi.org/10.1016/S1478-7482(07)80008-X.

(https://www.sciencedirect.com/science/article/pii/S147874820780008X)

59. Gotaas, Harold Benedict \& World Health Organization, (1956). Composting: sanitary disposal and reclamation of organic wastes / Harold B. Gotaas. World Health Organization.

60. Haug, R.T. (1993) The Practical Handbook of Compost Engineering. Lewis Publishers, Boca Raton.

61. Epstein, E. (1997). The Science of composting. Lancaster: Technomic.

62. Sussman, V. Easy Composting. Emmaus, Pennsylvania: Rodale Press. 1984. 